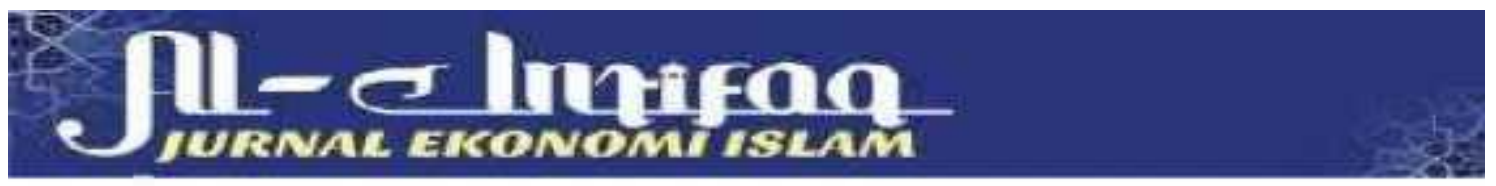

\title{
Analisis Kinerja Pegawai Kantor Wali Nagari Baringin Kecamatan Lima Kaum: Determinasi Kompensasi Dan Disiplin Kerja
}

\author{
Husni Shabri' ${ }^{1}$, Aini Yasri², Muhammad Deni Putra ${ }^{3}$ \\ Fakultas Ekonomidan Bisnis Islam, IAIN Batusangkar \\ husnishabri@iainbatusangkar.ac.id,mdeniputra@iainbatusangkar.ac.id
}

Abstract: This study aims to determine and analyze the effect of compensation and work discipline on the performance of the employees of the Baringin Lima Kaum office. This research type is field research with descriptive quantitative method. The results showed that compensation did not partially affect employee performance, but work discipline partially had a positive and significant effect on employee performance at the Baringin village office. While simultaneously compensation and work discipline have a positive effect on the performance of the employees of the Baringin village office, Lima Kaum District. The results of this assessment have a contribution to the management of the wali nagari contor in improving employee performance in the future.

Keywords: Employee Performance, Compensation, Work Discipline, Wali Nagari Baringin

Abstrak: Penelitian ini bertujuan untuk mengetahui dan menganalisis pengaruh kompensasi dan disiplin kerja terhadap kinerja pegawai kantor wali nagari Baringin Lima Kaum. Jenis penelitin ini adalah penelitian lapangan dengan metode kuantitatif deskriptif. Hasil penelitian menunjukan bahwa kompensasi tidak berpengaruh terhadap kinerja pegawai secara parsial, namun disiplin kerja secara parsial berpengaruh positif dan signifikan terhadap kinerja pegawai kantor wali nagari Baringin. Sedangkan secara simultan kompensasi dan disiplin kerja berpengaruh positif terhadap kinerja pegawai kantor wali nagari Baringin Kecamatan Lima Kaum. Hasil peneilian ini memiliki kontribusi bagi manajemen kontor wali nagari dalam meningkat kinerja pegawai di masa yang akan datang.

Kata Kunci: Kinerja Pegawai, Konpensasi, Disiplin Kerja, Wali Nagari Baringin

\section{PENDAHULUAN}

Tingkat disiplin kerja pegawai Kantor Wali Nagari Baringin Kecamatan Lima Kaum masih rendah sehingga mengakibatkan kinerja pegawai belum maksimal dalam melaksanakan tugasnya. Kompensasi yang sudah diberikan juga belum mampu meningkatkan kinerja pegawai. Rendahnya disiplin kerja dapat dilihat dari kehadiran pegawai di kantor yang datang terlambat. Tingkat keterlmbatan pegawai pada tahun 2019 mencapai 93,10\%, dimana rata-rata pegawai masuk kantor jam 8.30 - 9.00, sementara jadwal masuk kerja adalah jam 8.00. Demikian juga kompensasi yang diberikan berupa gaji, tunjangan, dan asuransi kesehatan sudah memenuhi syarat dan ketentuan yang berlaku.

Kajian tentang kinerja pegawai sudah banyak yang melakukan penelitian dari berbagai faktor yang mempengaruhinya. Seperti pengaruh kompensasi terhadap kinerja perangkat nagari dalam mengelola keungan (Suci, 2018), Pengaruh disiplin kerja terhadap kinerja perangkat nagari ( Yanti, ...), Pengaruh disiplin kerja, promosi jabatan dan kompensasi terhadap kinerja pegawai (Ardi, 2016), pengaruh kompensasi, 
pengembangan karir dan disiplin kerja terhadap kinerja pegawai ( Karnita\&Hadiat, 2014), pengaruh kompensasi terhadap kinerja pegawai (Marandeka, 2015). Penelitian kali akan mengkaji tentang kinerja pegawai kantor wali nagari Baringin Kecamatan Lima Kaum yang dipengaruhi oleh variable kompensasi dan disiplin kerja, dimana belum temukan penelitian terkait hal ini.

Penelitian ini bertujuan untuk mengetahui dan menganalisis pengaruh kompensasi dan disiplin kerja terhadap kinerja pegawai kantor wali nagari Baringin Kecamatan Lima Kaum. Penelitian ini dilakukan melengkapi berbagai penelitianpenelitian sebelumnya yang membahas tentang kinerja pegawai dari berbagai tempat. Kinerja pegawai menjadi hal suatu hal yang selalu menarik untuk diteliti karena kinerja adalah faktor penting dalam melihat ketercapai suatu tujuan dari suatu organisasi atau lembaga pemerintahan dalam memberikan layanan kepada masyarakat.

\section{KAJIAN TEORI}

\section{Kompensasi}

Kompensasi adalah setiap bentuk penghargaan yang diberikan karyawan sebagai sebagai balas jasa atas kontribusi yang mereka berikan pada organisasi (Pangabean, 2012), Kompensasi dapat dipahami sebagai setiap bentuk pembayaran atau imbalan yang diberikan kepada karyawanyang bekerja dalam suatu perusahaan (Dessler,2012). Dalam definisi lain Kompensasi adalah pembayaran dalam bentuk insentif untuk memotivasi karyawan agar produktivitas kerja semakin meningkat (Afifuddin, 2014). Oleh karena itu dapat dipahami bahwa kompensasi memiliki korelasi positif terhadap kinerja pegawai. Pemberian kompensasi dapat menjadi motivasi bagi pegawai untuk meningkatkan kinerjanya.

\section{Disiplin kerja}

Disiplin kerja merupakan kemampuan kerja seseorang untuk secara teratur, tekun secara terus menerus dan bekerja sesuai dengan aturan-aturan berlaku dengan tidak melanggar aturan-aturan yang sudah ditetapkan (Sinambela, 2017). Disiplin merupakan hal yang sangat penting bagi suatu organisasi atau perusahaan dalam mempertahankan atau melangsungkan kehidupannya. Hal ini disebabkan hanya dengan disiplin yang tinggi organisasi dapat berprestasi tinggi. Hal ini sesuai dengan pendapat Widjaja, sebagai berikut; dengan perkataan lain disiplin adalah unsur yang penting yang mempengaruhi prestasi dalam organisasi.

\section{Kinerja}

Schermerhorn Hunt dan Osborn menjelaskan kinerja sebagai kualitas dan kuantitas dari pencapaian tugas-tugas, baik yang dilakukan individu, kelompok, maupun organisasi (Sinambela,2017). Menurut Cardy (Noor, 2013) performance management is process of defining, measuring, appraising, providing feedback on, and impriving performance. dari pengertian ini dapat diuraikan bahwa mengelola kinerja sebaikanya dilakukan secara kolaboratif antara pegawai, pemimpin dan organisasi, melalui pemahaman dan penjelasan kinerja dalam suatu kerangka kerja atas tujuantujuan terencana, standar dan kompetensi yang disetujui bersama. Kinerja pegawai atau 
karyawan dalam suatu perusahaan atau organisasi dapat dipengaruhi oleh beberapa faktor seperti disiplin kerja, kompensasi, kemampuan dan keahlian, pengetahuan, motivasi kerja, kepribadian, budaya organisasi, gaya kepemimpinan, motivasi kerja, loyalitas dan komitmen.

\section{METODE PENELITIAN}

Peneitian ini merupakan penelitian lapangan (field reserarch) dengan metode deskriptif kuantitatif. Sumber data dalam penelitian ini adalah sumber data primer yang diperoleh langsung dari responden. Data primer yang pennulis maksud adalah penyebaran kuesioner kepada pegawai kantor Wali Nagari Baringin. Populasi dalam penelitian ini adalah seluruh pegawai yang melakukan pekerjaan di Kantor Wali Nagari Baringin yang berjumlah 28 orang. Teknik pengumpulan data menggunakan kusioner/angket. Angket yang digunakan dalam penelitian ini adalah angket tertutup yang menyediakan alternatif jawaban sehingga responden hanya memilih salah satu jawaban yang sudah tersedia. Data yang diperoleh akan diolah dengan memberikan sekor pada masing-masing butir pernyataan disusun dalam bentuk lima skala, yaitu: 5 . SS (sangat setuju), 4. S (setujua), 3. KS (kurang setuju), 2. TS (tidak setuju), dan 1. STS (sangat tidak setuju). Selanjutnya kuisioner yang sudah tersusun dilakukan uji validitas dengan korelasi product momment dan realibiltas dengan membandingkan nilai cronbach alpha pada taraf siqnifikansi 0,60.

Teknik analisis data yang digunakan dalam penelitian ini adalah analisis regresi linier berganda yang dibantu dengan software SPSS 22. Tahap pertama dilakukan uji asumsi klasik yang meliputi uji normalitas menggunakan normal p-plot, uji multikolinieritas dengan melihat nilai tolerance dan Variance Inflation Faktor (VIF), uji heteroskedastisitas dengan uji scatterplot. Setelah uji asumsi klasik terpenuhi kemudian dilanjutkan dengan analisis regresi linier berganda, uji t, uji F dan koofisien determinasi.

\section{HASIL DAN PEMBAHASAN}

\section{Uji Validitas}

Pengujian validitas menggunakan korelasi product moment. Kriteria validitas jika $\mathrm{r}$ hitung > r tabel maka item pernyataan dalam kuisioner dikatakan valid dan sebaliknya jika $\mathrm{r}$ hitung $<\mathrm{r}$ tabel maka item pernyataan dalam kuisioner dikatakan tidak valid. Berdasarkan hasil perhitung yang sudah dilakukan menggunakan aplikasi SPSS yang terlihat dalam tabel 1 menunjukan bahwa semua item pernyataan pada variabel kompensasi (X1) adalah valid. Hal ini terlihat bahwa nilai $r$ hitung setiap item pernyataan lebih besar dari nilai $\mathrm{r}$ tabel $(0,388)$

\section{Tabel 1.}

Uji Validitas Variabel Kompensasi $\left(X_{1}\right)$

\begin{tabular}{|c|c|c|c|}
\hline Item Pernyataan & $\mathrm{r}$ hitung & $\mathrm{r}$ tabel & Keterangan \\
\hline $\mathrm{X} 1.1$ & 0,896 & 0,388 & Valid \\
\hline
\end{tabular}




\begin{tabular}{|c|c|c|c|}
\hline X1.2 & 0,932 & 0,388 & Valid \\
\hline X1.3 & 0,859 & 0,388 & Valid \\
\hline X1.4 & 0,744 & 0,388 & Valid \\
\hline X1.5 & 0,753 & 0,388 & Valid \\
\hline X1.6 & 0,581 & 0,388 & Valid \\
\hline X1.7 & 0,762 & 0,388 & Valid \\
\hline X1.8 & 0,887 & 0,388 & Valid \\
\hline X1.9 & 0,767 & 0,388 & Valid \\
\hline X1.10 & 0,695 & 0,388 & Valid \\
\hline
\end{tabular}

Sumber: Data diolah

Tabel 2.

Uji Validitas Variabel Disiplin Kerja $\left(X_{2}\right)$

\begin{tabular}{|c|c|c|c|}
\hline Item Pernyataan & $\mathrm{r}$ hitung & $\mathrm{r}$ tabel & Keterangan \\
\hline X2.1 & 0,883 & 0,388 & Valid \\
\hline X2.2 & 0,795 & 0,388 & Valid \\
\hline X2.3 & 0,683 & 0,388 & Valid \\
\hline X2.4 & 0,547 & 0,388 & Valid \\
\hline X2.5 & 0,700 & 0,388 & Valid \\
\hline X2.6 & 0,577 & 0,388 & Valid \\
\hline X2.7 & 0,778 & 0,388 & Valid \\
\hline X2.8 & 0,781 & 0,388 & Valid \\
\hline X2.9 & 0,801 & 0,388 & Valid \\
\hline X2.10 & 0,615 & 0,388 & Valid \\
\hline
\end{tabular}

Sumber: Data diolah 
Berdasarkan tabel 2 pada penelitian ini untuk mengukur variabel disiplin kerja (X2) dengan 10 item pertanyaan, setelah dilakukan perhitungan dapat diketahui bahwa seluruh pernyataan dalam variabel disiplin kerja (X2) adalah valid. Hal ini terlihat bahwa nilai $r$ hitung setiap item pernyataan lebih besar dari nilai $r$ tabel $(0,388)$.

Tabel 3.

Uji Validitas Variabel Kinerja Pegawai (Y)

\begin{tabular}{|c|c|c|c|}
\hline Item Pernyataan & r hitung & $\mathrm{r}$ tabel & Keterangan \\
\hline Y.1 & 0,603 & 0,388 & Valid \\
\hline Y.2 & 0,685 & 0,388 & Valid \\
\hline Y.3 & 0,766 & 0,388 & Valid \\
\hline Y.4 & 0,584 & 0,388 & Valid \\
\hline Y.5 & 0,694 & 0,388 & Valid \\
\hline Y.6 & 0,553 & 0,388 & Valid \\
\hline Y.7 & 0,730 & 0,388 & Valid \\
\hline Y.8 & 0,718 & 0,388 & Valid \\
\hline Y.9 & 0,639 & 0,388 & Valid \\
\hline Y.10 & 0,498 & 0,388 & Valid \\
\hline
\end{tabular}

Sumber: Data Diolah

Berdasarkan tabel 3 pada penelitian ini untuk mengukur variabel kinerja pegawai (Y) dengan 10 item pertanyaan, setelah dilakukan perhitungan dapat diketahui bahwa seluruh pernyataan dalam variabel kinerja pegawai $(Y)$ adalah valid. Hal ini terlihat bahwa nilai $r$ hitung setiap item pernyataan lebih besar dari nilai $r$ tabel $(0,388)$.

\section{Uji Reliabilitas}

Uji Reliabilitas dilakukan untuk mengetahui dan menilai konsistensi dari alat ukur atau instrument penelitian. Suatu instrument variabel penelitian dikatakan realibel jika Nilai Cronbach's Alpha lebih besar dari standar pengujian (a) 0,60.

Tabel 4

Hasil Uji Reabilitas

\begin{tabular}{|c|c|c|}
\hline Variabel & Cronbach's Alpha & N of Items \\
\hline Kompensasi (X1) & 0.933 & 10 \\
\hline Disiplin Kerja (X2) & 0.895 & 10 \\
\hline
\end{tabular}




\begin{tabular}{|l|l|l|}
\hline Kinerja Pegawai (Y) & 0.843 & 10 \\
\hline
\end{tabular}

Sumber: Data Diolah

Berdasarkan tabel diatas semua variabel penelitian memilik nilai Cronbach's Alpha lebih besar dari 0,60 yang menunjukan bahwa semua variabel dalam penelitian ini sudah realibel.

\section{Uji Asumsi Klasik \\ Uji Normalitas}

Uji normalitas berguna untuk mengetahui apakah variabel dependen, independen atau keduanya berdistribusi normal, mendekati normal, atau tidak. Hal ini dapat dilihat sebagai berikut:

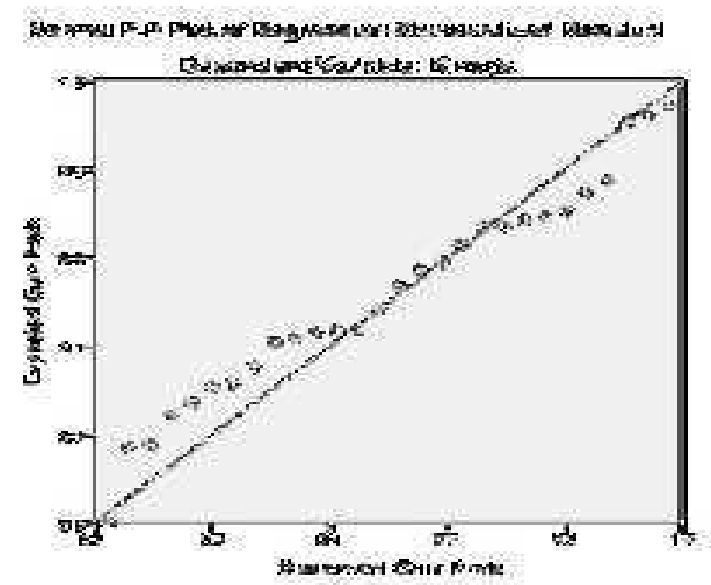

Berdasarkan gambar 1 dapat dilihat bahwa variabel dependen (kinerja pegawai) dan independen (kompensasi dan disiplin kerja) berdistribusi dengan normal. Grafik normal probability plot menyebar mengikuti garis tengah kurva dan tidak meluas, dari hasil tersebut berarti model regresi layak dipakai karena memenuhi asumsi normalitas.

\section{Uji Multikolinieritas}

Uji multikolinieritas bertujuan untuk menguji apakah ditemukan adanya korelasi antar variabel independen atau bebas. Menurut Ghozali (2018:105), tujuan uji multikolinieritas adalah untuk menguji apakah model regresi ditemukan adanya korelasi antar variable bebas. Model regresi yang baik memiliki model yang di dalammnya tidak terjadi korelasi diantara variabel independen. Uji multikolonieritas dilihat dari nilai tolerance dan Variance Inflation Faktor (VIF). Apabila nilai tolerance $>$ 0,1 dan nilai VIF 10, berarti tidak terdapat multikolonieritas. Jika nilai tolerance $<0,1$ dan nilai VIF 10 maka terdapat multikolonieritas dalam data.

Tabel 5

Hasil Uji Multikoliniearitas

\begin{tabular}{|c|c|c|}
\hline Model & Tolerance & $\begin{array}{c}\text { ty Statistics } \\
\text { VIF }\end{array}$ \\
\hline $\begin{array}{l}1 \text { (Constant) } \\
\quad \text { Kompensasi }\end{array}$ & .924 & 1.082 \\
\hline
\end{tabular}




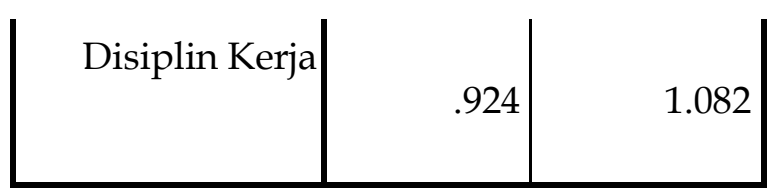

Sumber: Data Olahan

Berdasarkan hasil pada tabel 4.8, terlihat nilai tolerance 0,924 dengan nilai VIF sebesar 1,082, yang berarti hasil tersebut nilai tolerancelebih besar dari 0,10 dan VIP kurang dari 10, dari hasil tersebut dapat disimpulkan bahwa model regresi yang digunakan dalam peneleitian ini terbebas dari multikolinearitas.

\section{Uji Heteroskedastisitas}

Heteroskedastisitas adalah suatu uji yang bertujuan untuk menguji apakah dalam model regresi terjadi ketidaksamaan varians dan residual atau pengamatan ke pengamatan yang lain, jika variansnyaa berbeda maka itu disebut heteroskedastisitas. Model regresi yang baik adalah tidak terjadi heteroskedastisitas, dalam penelitian ini peneliti menggunakan metode grafik dimana jika hasil dari pengolahan memperlihatkan pola tertentu seperti titik-titik yang ada membentuk suatu pola yang teratur maka terjadi heteroskedastisitas dan maka apabila tidak membentuk pola tertentu seperti titik-titik menyebar di atas dan di bawah angka 0 pada sumbu $Y$, maka terjadi heteroskedastisitas (Priyatno, 2014)

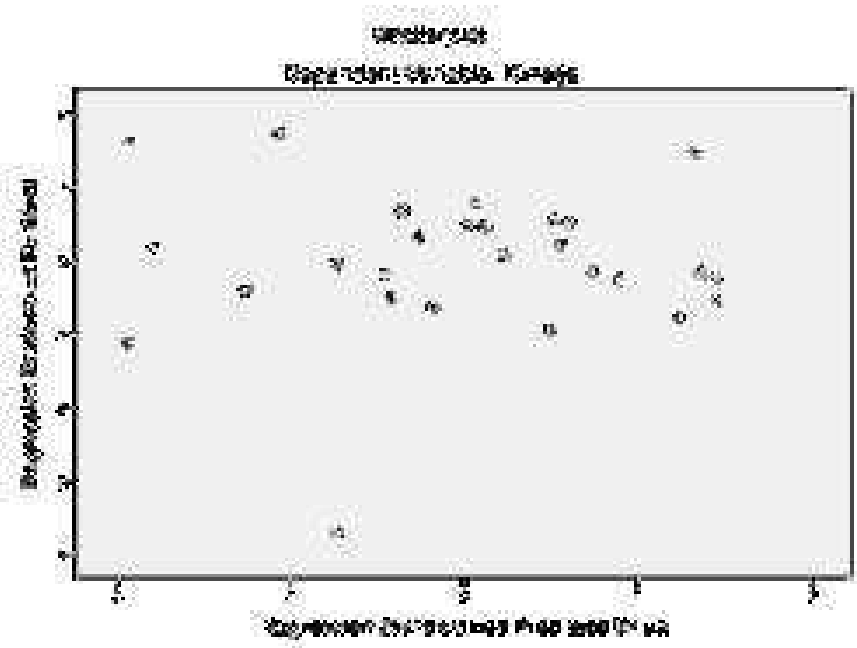

Gambar 2

Hasil Uji Heteroskedastisitas-Scatterplot Sumber: Data Diolah

Berdasarkan grafik scatterplot menunjukan bahwa tidak ada pola yang jelas, serta titik-titik menyebar di atas dan di bawah angka 0 pada sumbu Y. Jadi dapat dikatakan dalam model regresi ini tidak terjadiheteroskedastisitas, sehingga model regresi layak dipakai untuk variabel kompensasi dan disiplin kerja yang menginterprestasikan variabel kinerja.

\section{Analisis Regresi Linier Berganda}

Analisis regresi linear berganda ini bertujuan untuk memprediksi pengaruh variabel independen (kompensasi dan disiplin kerja) terhadap variabel dependen (kinerja pegawai). Hasil analisis yang penulis teliti adalah sebagai berikut: 
Tabel 6

Analisis Regresi Linear Berganda

\begin{tabular}{|l|r|r|r|}
\hline & \multicolumn{2}{|c|}{$\begin{array}{l}\text { Unstandardized } \\
\text { Coefficients }\end{array}$} & $\begin{array}{c}\text { Standardized } \\
\text { Coefficients }\end{array}$ \\
Model & \multicolumn{1}{|c|}{ B } & Std. Error & \multicolumn{2}{|c|}{ Beta } \\
$\begin{array}{l}\text { Konstant) } \\
\text { Kompensas }\end{array}$ & 18.680 & 9.556 & \\
$\begin{array}{l}\text { Disiplin } \\
\text { Kerja }\end{array}$ & .151 & .107 & .262 \\
\hline
\end{tabular}

Sumber: Data Diolah

Analisis regresi linear dapat dijadikan ke dalam persamaan sebagai berikut :

$Y=18,680+0,151 X 1+0,410 X 2$ Persamaan ini

memiliki arti :

a) nilai konstanta sebesar 18,680 . Hal ini berarti apabila kompensasi (X1) sama dengan nol dan disiplin kerja (X2) sama dengan nol maka kinerja nilainya adalah 18,680.

b) Koefisien regresi kompensasi (X1) sebesar 0,151 yang berarti variabel kompensasi berpengaruh positiif terhadap kinerja pegawai (Y). Dan menunjukan bahwa dengan adanya kompensasi, akan terjadi peningkatan kinerja sebesar 0,151.

c) Koefisien regresi disiplin kerja (X2) sebesar 0,410 yang berarti variabel disiplin kerja berpengaruh positiif terhadap kinerja pegawai $(\mathrm{Y})$. Dan menunjukan bahwa dengan adanya disiplin kerja, akan terjadi peningkatan kinerja sebesar 0,410.

\section{Uji Hipotesis}

\section{Ujit}

Variabel kompensasi secara persial tidak berpengaruh signifikan terhadap variabel kinerja. Berdasarkan uji t menunjukan bahwa t-hitung kompensasi sebesar 0,719 lebih kecil dari t-tabel 2,05954, demikian juga dengan tingkat signifikan 0,478 lebih besar dari 0,05 .

Variabel disiplin kerja secara persial berpengaruh signifikan terhadap variabel kinerja. Berdasarkan uji t menunjukan bahwa t-hitung disiplin kerja sebesar 2,360 lebih besar dari t-tabel 2,05954 dengan tingkat signifikan 0,025 lebih kecil dari 0.05 .

\section{Uji F}

Uji F digunakan untuk mengetahui pengaruh semua variabel independen yang dimaksudkan dalam model regresi secara bersama-sama terhadap variabel dependen, yang berarti pengaruh kompensasi dan disiplin kerja secara bersama terhadap kinerja pegawai. Variabel kompensasi dan disiplin kerja secara bersama-sama berpengaruh signifikan terhadap variabel kinerja pegawai pada kantor Wali Nagari Baringin. Hal ini 
dapat dilihat dari nilai F-hitung sebesar 3,414 lebih besar dari F-tabel 3,37 dan nilai siq 0,041 lebih kecil dari 0,05.

\section{Koefisien Determinasi (R2)}

Koefisien Determinasi (R2) untuk mengetahui kontribusi variabel kompensasi dan disiplin kerja terhadap kinerja pegawai dapat dilihat pada tabel 7. Nilai Koefisien Determinasi (R2) sebesar 0,201 atau 20,1\% yang berarti bahwa variabel kompensasi dan disiplin kerja memiliki konstribusi mempengaruhi kinerja pegawai hanya sebesar 20,1\% sedangkan sisanya sebesar 79,9\% dipengaruhi oleh faktor-faktor lain yang tidak diteliti dalam penelitian ini.

Tabel 7

Hasil Uji Koefisien Determinasi $\left(\mathbf{R}_{2}\right)$

\begin{tabular}{|l|r|r|r|r|c|}
\hline & & & & & \\
Model & $\mathrm{R}$ & R Square & $\begin{array}{c}\text { Adjusted R } \\
\text { Square }\end{array}$ & $\begin{array}{c}\text { Std. Error of } \\
\text { the Estimate }\end{array}$ & $\begin{array}{c}\text { Durbin } \\
-\end{array}$ \\
\hline 1 & $.448^{\mathrm{a}}$ & .201 & .137 & 3.383 & 1.514 \\
\hline
\end{tabular}

Sumber: Data Diolah

\section{Pengaruh Kompensasi Terhadap Kinerja Pegawai}

Variabel kompensasi memiliki t-hitung yang bernilai positif yakni 0,719 lebih kecil dari t-tabel 2,05954, dengan demikian dapat dikethaui bahwa kompensasi secara persial tidak berpengaruh terhadap kinerja pegawai di kantor Wali Nagri Baringin. Oleh karena itu peningkatan kinerja pegawai di kantor Wali Nagari Baringin tidak dapat dilakukan jika hanya menambah atau meningkatkan kompesasi secara parsial tetapi membutuhkan variabel lain. Hasil penelitian ini berbeda dengan penelitian sebelumnya yang hasilkan kompensasi berpengaruh siqnifikan terhadap kinerja pegawai ( Karnit\& Hadiyat, 2014)

\section{Pengaruh Disiplin Kerja Terhadap Kinerja Pegawai}

Variabel disiplin kerja meliliki t-hitung yang bernilai postif yakni 2,360 lebih besar dari t-tabel 2,05954, yang berarti bahwa disiplin kerja secara persial berpengaruh terhadap kinerja pegawai di kantor Wali Nagari Baringin, dari hasil tersebut berarti disiplin kerja mampu secara persial memberikan pengaruh dalam meningkatkan kinerja pegawai di kantor Wali Nagari Barinngin. Hasil penelitian ini juga sejalan dengan penelitian yang dilakukan oleh (Hafulyon, 2016, Arsi,2016) yang menyatakan bahwa disiplin kerja berpangaruh terhadap kinerja pegawai.

\section{Pengaruh Kompensasi dan Disiplin Kerja Terhadap Kinerja Pegawai}

Nilai $\mathrm{F}$ tabel (k;n-k) dimana $\mathrm{k}$ adalah jumlah variabel independen dan $\mathrm{n}$ adalah jumlah sampel, maka $(2 ; 28-2)=(2 ; 26)$ dengan taraf signifikan 0,05 atau $5 \%$ maka diperoleh F tabel 3,37. Sehingga dapat disimpulkan F-hitung sebesar 3,414 lebih besar 
dari F-tabel 3,37 maka variabel kompensasi dan disiplin kerja secara bersama-sama berpengaruh signifikan terhadap variabel kinerja pegawai, Hal ini menjelaskan bahwa kompensasi dan disiplin kerja bersama-sama berpengaruh signifikan terhadap kinerja pegawai kantor Wali Nagari Baringin, artinya jika kompensasi dan disiplin kerja baik maka akan meningkatkan produktifitas kinerja, begitu juga sebaliknya.

\section{KESIMPULAN DAN KONTRIBUSI PENELITIAN Kesimpulan}

Hasil penelitian pengaruh kompensasi dan disiplin kerja terhadap kinerja pegawai kantor Wali Nagari Baringin Kecamatan Lima Kaum diperoleh kesimpulan sebagai berikut:

1. Kompensasi secara uji persial tidak berpengaruh terhadap kinerja pegawai pada kantor Wali Nagari Baringin Kecamatan Lima Kaum.

2. Disiplin kerja secara uji persial bepengaruh terhadap kinerja pegawai pada kantor Wali Nagari Baringin Kecamatan Lima Kaum.

3. Kompensasi dan disiplin kinerja secara simultan atau bersama-sama terdapat pengaruh positif dan signifikan terhadap kinerja pegawai pada kantor Wali Nagari Baringin Kecamatan Lima Kaum. Kontribusi dua variabel ini mempengaruhi kinerja pegawai hanya sebesar 20,1\% sisanya sebesar 79,9\% dipengaruhi oleh varibael-variabel lain yang tidak diteliti.

\section{Kontribusi Penelitian}

Adanya pengaruh kompensasi dan disiplin kerja secara bersama-sama terhadap kinerja pegawai, maka diharapkan bagi pihak kantor Wali Nagari Baringin Kecamatan Lima Kaum untuk dapat melaksanakan dan meningkatkan indikator tersebut dalam meningkatkan kinerja. Selain itu diharapkan agar bisa mencari faktor lain yang juga bisa mempengaruhi kinerja pegawai selain indikator yang penulis uraikan dalamm penelitian ini.

\section{DAFTAR PUSTAKA}

Afifuddin. 2014. Manajemen Personalia. Bandung: CV Pustaka Setia.

Achmad, S. 2010. Metodologi Riset Manajemen Sumber Daya Manusia. Jakarta: UIN Maliki Press

Asnawi, N., \& Masyhuri, 2011.Metodologi Riset Manajemen Pemasaran. Cetakan II. Malang: UIN Press.

Armansyah, A. dkk. 2018. Pengaruh Kompensasi dan Disiplin Kerja terhadap Kinerja Pegawai Kantor BPJS Kesehatan Cabang Palu. Jurnal Ilmu Manajemen Uvniversitas Tadulako 4 (3).

Darsono\& Siswandoko, 2011. Manajemen Sumber Daya Manusia Abad 21. Jakarta: Nusantara Consulting.

Ghozali, I. 2018. Aplikaisi analisis Multivariete SPSS 25. (9thed) Semarang: Universitas Diponegoro

Hasbidin. 2017. Faktor-Faktor Yang Berpengaruh Terhadap Kinerja Pegawai Bank Syariah Mandiri Di Kota Medan. At-Tawassuth 2 (1). 
Hafulyon, \& Fitria, R. 2015. Manajemen Sumber Daya Manusia. Batusangkar: STAIN Batusangkar Press.

Iswandiari, A. 2017. Pengaruh Kompensasi dan Disiplin Kerja terhadap Kinerja Karyawan Bagian Produksi PG. Matijan Kediri, Jurnal JIBEKA 11 (1).

Kasmir. 2016. Manajemen Sumber Daya Manusia Teori dan Praktik. Jakarta: PT Raja Grafindo Persada.

Karnita, L, \& Hadiat, E. 2014. Pengaruh Kompensasi dan Pengembangan Karier dan Disiplin Kerja terhadap Kinerja Pegawai Dinas Pendapatan Daerah Kota Cimahi. Jurnal Ekonomi, Bisnis, dan Entrepreneurship 8 (2)

Marandeka, A. 2015. Pengaruh Kompensasi terhadap Kinerja Pegawai pada Kantor Sekretariat DPRD Provinsi Kalimantan Timur. Jurnal Ilmu Administrasi Bisnis 3 (2)

Noor, J. 2013. Penelitian Ilmu Manajemen Tinjauan Filosofis dan Praktis. Jakarta: Kencana

Priyatno. D. 2014. Pengolahan Data Terpraktis Dengan SPSS 22, Yogyakarta: CV Andi Offset.

Prasetyo Ardi, R. 2016. Pengaruh Disiplin Kerja, Promosi Jabatan dan Kompensasi terhadap Kinerja Pegawai pada Dinas Kebudayaan Pariwisata Pemuda dan Olahraga Kabupaten Rembang. Jurnal EBBANK 7 (2).

Sutrisno, E. 2012. Manajemen Sumber Daya Manusia. Jakarta: Kencana.

Sinambela, L. P. (2017). Mnajemen Sumber Daya Manusia. Jakarta: Bumi Aksara.

Sugiyono. 2014. Metode Penelitian Manajemen Pendekatan Kuantitatif, Kualitatif, Kombinasi (Mixed Method), Penelitian Tindakan (Action Research) Penelitian Evaluasi. Bandung: Alfabeta.

Suci, R. 2018. Pengaruh Kompensasi terhadap Kinerja Perangkat Nagari dalam Pengelolaan Keuangan Nagari Di Kecamatan Salimpaung. Jurnal euducation on social science (2) 1

Satedjo, A. D. \& Kempa. 2017. Pengaruh Kompensasi dan Disiplin Kerja Terhadap Kinerja Karyawan PT. Modern Widya Tehnical Cabang Jayapura, Jurnal Agora $5(3)$.

Utami, F.M. 2014. Pengaruh Kompensasi dan Disiplin Kerja Terhadap Kinerja Karyawan Studi Kasus Pada PT. Gapura Omega Alpha Land Depok. Skripsi Program Strata 1, UIN Sayrif Hidayatullah: Jakarta.

Yanti, R. 2015. Pengaruh Disiplin Kerja terhadap Kinerja Perangkat Nagari dalam Pengelolaan Perangkat Nagari di Kecamatan Banuhampu dan Sungai Tua. 